\title{
THE PURIFICATION OF VIOLENCE AND THE TRANSLATION OF FAIRY TALES: A CORPUS-BASED STUDY
}

\author{
Cybelle Safa Soares ${ }^{{ }^{*}}$ \\ ${ }^{1}$ Universidade Federal de Santa Catarina, Florianópolis, Santa Catarina, Brasil
}

\begin{abstract}
This study aims to investigate the translation of violence, to propose and to analyse the translation strategies of English Fairytales (EFT) to the Portuguese language. The theoretical framework of this study is based on the interface of Corpus-based Translation Studies (CTS) and Descriptive Translation Studies (DTS). Klingberg's (1986) purification concept adapted as translation strategies proposed by Chesterman (1997). For the alignment and corpus analysis, COPA-TRAD - Parallel Corpus for translation research (Fernandes, L. \& Silva, 2014) is used. The analysis revealed that the target text had been translated under moral and religious motivational factors of the source culture because the literature translated in Brazil still had to comply with the Portuguese requirements for translating for children (Coelho, 1987).

Keywords: Translation of Children's Literature; Fairy tales; Purification; Corpus-based Translation Studies.
\end{abstract}

\footnotetext{
* Possui mestrado em inglês pela UFSC (PPGI). Atualmente é doutoranda no Programa de Pós Graduação em Inglês (PPGI) na Universidade Federal de Santa Catarina (UFSC). Seu e-mail é cybellesaffa@gmail.com. ORCID: http://orcid.org/0000-0001-7617-4654.
} 


\section{Introduction}

Fairy tales come from the oral tradition of folklore and have been spread out by word of mouth for centuries. The stories have had their plots adapted from adults to child readers as to suit the requirements of the ever-changing idea of childhood. These narratives are enriched with whimsical creatures and carry fantastic events that take place in magical worlds detached from our own time and space. In these worlds, it is possible to find supernatural and fantastic beings, such as talking animals, giants, goblins and "sometimes" fairies; I say "sometimes" because they are not always there. Thereupon, these stories have sewn together linguistic and cultural elements, coming from multifarious origins, which we now share as our own. Zipes (1999) reveals that the language in these tales was also symbolic and "could be read on so many different levels that they were considered somewhat dangerous" (p. 336).

Some of the tales carried out plots with children's death, killing, robbery, abandonment and a great deal of other issues that underwent under purification before reaching the ears and the imagination of a child. Jacobs (1891) in his preface to the first edition of English Fairy Tales acknowledges the necessity of making some deviations from the "original" as to make the tales readable for children - "it has been my ambition to write as a good old nurse when she tells fairy tales."

The history of the Translation of Children's Literature (TCL) shows that when travelling from one cultural and linguistic system to another, most fairy tales went through processes of purification as to suit the prevailing society's moral, educational and religious requirements. In Brazil, the last two have been the threshold to the creation of commissions to intervene in the production and translation of Children's Literature. There were even lists of books which could and could not be translated (Bertoletti, 2012). By and large, translating for children in Brazil at the beginning of the twentieth century implied that the translator should work in conformity to fulfilling the requirements of these commissions. In like manner, most of the English fairy tales translated in Brazil featured the presence of situations of violence involving children, their relatives, and other characters and had to be purified. From this standpoint, the present study aims at bringing to light this violence represented through the physical actions performed by the characters and the translation strategies adopted to purify this violence.

Within the area of TCL, this study adopts the categories for cultural adaptation suggested by Klingberg (1986) with a focus on purification, namely, a kind of censorship leading to abridgements of stories to suit specific requirements of a target language - mostly known within the field of TCL. Klinberg's approach towards the TCL is rather prescriptive as he concentrates on the formulation of rules for translators. So, this study is carried out under Descriptive Translation Studies (DTS), adapting Klingberg's categories that turned out suitable for describing the phenomenon of purification in the Translation of Children's Literature (TCL). 
The cultural aspects were the main wellspring for having chosen this topic of purification in the TCL, as well as the fact that there are very few studies involving the translation of fairy tales and the purification in translations to the Portuguese language in Brazil and other countries.

When it comes to fairy tales, most translators of Children's Literature, in Brazil and around the globe, acknowledge their adaptations as to suit their target audiences, and for that, they resort to deletions and substitutions, as we can see in Joseph Jacobs' works in the following section.

\section{Joseph Jacobs’ English Fairy Tales}

Joseph Jacobs was born Australian but moved to England at the age of 18, in 1827. He studied anthropology at King's College and later became e member of the English Folk-Lore Society. The author created the Folk-Lore Journal, being himself the chief editor. In the years that followed, he dedicated to the collection of folk tales that were to compose the two volumes of stories for children: English Fairy Tales (1890) and More English Fairy Tales (1894), illustrated by John D. Batten. Also, he included notes to both volumes in which he provides explanations for the collection process as well as for the linguistic adaptations. Amongst the adaptions are the exclusion of what he calls vulgarisms and the simplification of lengthy phraseology from the eighteenth century. He intended to provide English children with stories that were meant to be read aloud, "fairy tales which English children will listen to [...] and not merely taken in by the eye" (Jacobs, 1980). Jacobs was also an inveterate softener, and Chatton understands that

Unlike other folklorists, Jacobs believed in altering tales to fit his young audiences, omitting incidents he felt were too violent or coarse, changing episodes to make them more attractive, and developing language when he felt it was too complicated or dialect-laden. He was careful, however, to acknowledge his written sources and to include notes and references at the back of each book that tell adults about the changes he has made and his reasons for making them. (Chatton, 1995, p. 348)

Different from Joseph Jacobs, the translators of the English fairy tales to the Portuguese language do not acknowledge the adaptations made to the stories. On the contrary, it is hard to find any preface or footnotes that give reasons for the need of any alterations, such as, linguistic, literary or even ideological ones.

\section{Os mais belos contos de Fadas ingleses}

The first volumes from the collection Os mais belos contos de Fadas from all nations were first published in 1940, and the first edition of Os mais belos contos de Fadas ingleses was released in Brazil in 1944 by Editora Vecchi. This version did not provide the translator's name, just the illustrator's, Ramon Hespanha. The mention of the translators only appeared ten years later in the fifth edition. The 
translator responsible for the translation of the English-Portuguese linguistic pair was Persiano da Fonseca. This edition has the same fairy tales as the first one with no significant alterations.

Compared to the source text English Fairy Tales, Os mais belos contos de Fadas ingleses brings a list of thirty-four tales out of a total of forty-three from the English edition. There is a predominance of stories with magical creatures, such as giants, desolate realms and slaughtering humans. All deaths occurred in the name of God.

\section{The purification of violence}

If we go back to the introduction of this article, we find reference to the folklorist Joseph Jacobs and his acknowledgement of altering the folk tales collected before they turned into their written versions of fairy tales. On these grounds, Zipes (1999) observes that for many centuries translations of fairy tales suffered adaptations mainly due to the non-acceptance of these stories in their "original form" by society, given the fact that fairy tales convey subversive features in language and at times in the whole plot. For that reason, they had to be "sanitised" (p. 336). Malarte-Feldman (2008) emphasises that these tales, when adapted, changed into "new versions or variants" (p. 43).

According to Blamires (2006), Edgar Taylor (1793-1839), a British legal writer and translator, was an "inveterate softener" and used to signal all adaptations made in his translations by editing and adding a note at the end of each tale. He also tried to avoid translating the tales which carried frightening plots or the ones which portrayed cannibalism or any physical violence. He wanted the stories to end happily ever after, even though nowadays some of his translations still carry some level of violence.

So, purification is the elimination, deletion and omission of linguistic items and/or themes that are considered to go against "the set of values of the adult intermediary" (Klingberg, 1986). It primarily involves the processes of cultural adaptations and can only be applied when the Translation of Children's Literature is at stake.

In the Brazilian translation scenario of the nineteenth century, Arroyo (2010) points out that the translations of fairy tales had pedagogical purposes with a didactic aim and mostly because of the adoption by schools. Zilberman (2003) stresses that the alterations in the translation of literature oriented to the child reader in Brazil at the time didacticized and oriented the child towards the adult's perspectives of proper moral values and good conduct.

By this means, fairy tales have undergone a process of translation through purification with the aim of adjusting the plots to the proposed set of values which schools and society demanded. The translations, in this case, might have been made in one of the categories here adapted from Klingberg's (1986) cultural context adaptations. They are "(1) added explanation; (2) rewording; (3) explanatory translation; (4) explanation outside the text; (5) substitution of 
an equivalent in the culture of the target language; (6) substitution for a rough equivalent in the culture of the target language; (7) simplification; (8) deletion and (9) localization" (p. 18). For this study, these categories add meaning to purification in TCL for the reason that they are somehow reflected in the Target Texts (TT) here analysed and applied with the aim of identifying the purification strategies the TT.

\section{My mother slew me: defining violence}

In fairy tales, nearly every character - from the most hardened criminal to the Virgin Mary - is capable of outrageous behaviour. (Tatar, 1999, p. 365)

Tatar scrutinised some German fairy tales to find out that "nearly every character is capable of cruel behaviour" (p. 365). To demonstrate that, she gives the example of Grimms' Cinderella's stepsisters: "so both sisters were punished with blindness to the end of their days for being so wicked and false (p. 366). Bottigheimer (2000) suggests that it is important to realise that many of the Grimms' tales were removed from collections to children due to the fact of containing egregious violence (p. 208).

Scholars from the field of Translation of Children's Literature, Folklore Studies and the studies of Children's Literature have identified that many fairy tales from diverse cultural scenarios have suffered some purification. They agree that most of what has been avoided to translate is related to violence or to any other kind of subversion or taboo having sometimes one or another tale omitted from a collection of stories.

So, what is violence? According to Holbrook (2009) in the Cambridge dictionary of psychology, violence is "described as any physical action perpetrated with the deliberate intention of harming, violating, or damaging the victim" ( $\mathrm{p}$. 570). The author categorises murder and "physical assault" as "extreme cases of individual violence". The Merriam-Webster's Collegiate Dictionary also focuses on the exertion of physical force with the intention to injure or abuse someone. The Portuguese language dictionary Houaiss 1 adds to the previous definitions: the quality of what is violent. ${ }^{2}$

"The Juniper Tree" has descriptions of excessive violence. It tells a story of a stepmother who beheads her stepdaughter and cooks the girl's heart and liver for supper. The girl's father ends up eating his daughter's organs without knowing it. Its English variant "The Rose Tree" also brings "cannibalism, death and retribution". Tatar (1999) goes on to say that with "its lurid descriptions of decapitation and cannibalism, [this is] probably the most shocking of all fairy tales" (p. 183). The presence of these cruel scenes might be the reason why Editora Vecchi did not translate this fairy tale and as a consequence, the story is not included in Os mais belos contos de Fadas ingleses. 
Table 1 - Violence

The Rose-tree

Well! She laid down her little golden head without fear; and whist! Down came the axe, and it was off. So the mother wiped the axe and laughed.

Then she took the heart and liver of the little girl, and she stewed them and brought them into the house for supper.

My wicked mother slew me, My dear father ate me [...]

At the beginning of the nineteenth century, in Brazil, the literature translated for children had as its primary purpose the acquisition of ethical and moral norms and by this means had to adapt or even delete passages which did not act accordingly.

Tatar (1993) in the chapter "The Pedagogy of Fear in Fairy Tales" describes and points out some exemplary tales about disobedience and its consequences. In the fairy tales proposed to the analysis in this study, we can identify some which convey this message of fear and death threat all aiming at teaching children a lesson. Nodelman (2008) highlights that "children's literature teaches beyond its obvious messages [it] shapes individuals' subjectivities into conforming to societal constraints" (p. 157). The author also debates the continual need for parental protection and in a way provides whys and wherefores for the recurrence of monstrous violence in the pages of fairy tales to vindicate children's need for adult protection.

The TT Os mais belos contos de Fadas ingleses provides readers not only with an extensive array of monstrous atrocities committed by giants and ogres but also with brutal, indiscriminate mass slaughter perpetrated by the heroes all justified in the name of safeguarding the defenceless and the helpless. The following section goes on to identify the textual representation of violence under the premise and definition reported in this section.

\section{Violent actions represented}

Violence is textually represented and identified in the tales with verbal expressions, which always convey as an intention to harm someone. English Fairy Tales' characters can be strangled, smothered, hung, just to mention some. The verbs that convey the meanings of violence can thus incorporate other senses; to put it another way, violence here is the "superordinate" term and kill, chuck, hang, mutilate examples of "hyponyms" of violence. According to Hatim, B. \& Munday (2004), these words represent the hierarchic structuring for semantic analysis. They cover lexical items within the same semantic category, for instance, cannibalism involves eating, and eating involves chewing, swallowing and devouring. As a result, we can say that meanings here move from a "noun" that holds the umbrella - the superordinate - and the lexical items with more accurate meanings - the hyponyms. The following table exemplifies cannibalism as superordinate. 
Table 2 - Superordinate and hyponym

\begin{tabular}{l|l|l|l|l}
\hline \multicolumn{5}{c}{ Cannibalism } \\
\hline Eat & Have & Chew & Swallow & Devour \\
\hline
\end{tabular}

Cannibalism is the superordinate and eat, have, chew, swallow, and devour are its hyponyms. Each of them carries the meaning of eating human flesh or the flesh of an animal of the same kind. This hierarchic structuring of the superordinate and the hyponym helped to compose the basis for the analysis of the fairy tales and to delimit the purification items to go into the purification strategies.

\section{Translation strategies}

Klingberg (1986) assigns to purification the textual components which conflict with the cultural, moral, religious and educational values of the target system. Under those circumstances, the translator's solution to tackling doubtful values lays mainly on the strategies applied in translation processes. These solutions are here referred as translation strategies, defined by Chesterman (1997) as "potentially conscious plans or decisions for solving a transition problem" (p. 268). These decisions can be global and local, being the first applied to the "translator's initial decision about the general nature of the relationship between target and source texts" (p. 90) and the second to the intertextual relationship between source and target text. Adding to the global and local decisions are the communication strategies, subdivided into comprehension and production strategies. The first concerns a cognitive analysis of the ST (process) and the second the manipulation of the TT aiming at complying with its cultural system. Thereupon, the local strategy is the one which most suits the analytical purpose of this study about intertextual matters.

Immediately, Chesterman (1997) subdivides the local strategy into syntactic (form), semantic (meaning), and pragmatic (manipulate the message itself and can be a result of the global strategy). From those last given strategies, this study focuses on the semantic as it considers the transference of meaning from source to target text, including the ST (superordinate) $\leftrightarrow$ ST/TT (hyponym), for instance: ST (devouring) $\leftrightarrow$ TT (swallowed). Given these points, the ST yields the superordinate and the TT returns the hyponyms.

As described above, a superordinate holds the general meaning of the hyponyms within each category. For instance, if chew is in the sense of eating, hence chew is a hyponym of the superordinate eat. In the same token chew and eat are hyponyms of the superordinate cannibalism. Under those circumstances, the superordinates that best cover the hyponyms found in the STs are (i) mutilation; (ii) cannibalism, (iii) killing and death threat; (iv) hanging; (v) physical injury; (vi) devouring. These superordinates are a result of a parallel 


\section{Purification strategies}

Klingberg (1986) suggests nine strategies for cultural context of adaptation. These strategies were reduced to a total of five and had been adapted to the purpose of the analysis for this research and used as purification strategies. The reason for this adaptation is due to the fact of their high frequency in the TT and for not having any other adequate strategies suitable for the analysis here proposed. Above all, he stresses that "it is not possible to draw up rules applicable in all instances. Every passage [to be translated] has its problems" (p.19).

Hence, regarding a similarity between some of the purification strategies, namely the fifth and the sixth ones - (5) substitution for an equivalent in the culture of the target language, (6) substitution for a rough equivalent in the culture of the target language - they have not been selected. In the same fashion, the localisation strategy was left out because of the lack of occurrences in most of the translated fairy tales. Therefore, the purification strategies for the analysis are (1) deletion; (2) added explanation; (3) substitution of an equivalent; (4) rewording. They have been agglutinated reflecting the characteristics of the TT.

\section{The corpus}

There are forty-three fairy tales in the first edition of English Fairy Tales published in 1890. It belongs to the public domain and is available for download from the Gutenberg Project. Also, the fairy tales translated into the Portuguese language are the ones from this edition; they even appear in the same order in the list of contents on ST and TT.

The TTs are composed of thirty-four fairy tales from Os mais belos contos de Fadas ingleses published in 1954. It is the fifth edition and the one that mentions the translator, Persiano da Fonseca.

There is a difference of 9 tales between the ST and TT. This omission of some of the tales from the STs was the first evidence that TTs had been under some purification. Henceforth, for the analysis, the thirty-four fairy tales which are common to the ST and TT are considered; that is, the number of fairytales that compose the TT. Lastly, the Brazilian Os mais belos contos de Fadas ingleses comes to be the first volume to have published most of the fairy tales from the English Fairy Tales.

\section{Corpus building}

The digitalisation phase follows the selection of the corpus. This step is crucial to the analytical procedure, as the texts have to be in digital format before they are aligned and inserted in comparable corpora software. Dr Lincoln Fernandes and his doctorate student Carlos Silva developed COPA-TRAD, a parallel translation corpus designed for teaching and learning, for translation practice and researching. This computational tool was developed for the translator/researcher to get familiar 
with the data in a more efficient way. This tool optimises the translation researcher's work as it is capable of retrieving a large amount of data and offers the possibility of identifying specific linguistic items through a parallel search. COPA-TRAD consists of four subcorpora: COPA-TEJ, COPA-MET, COPA-TEL, and COPA-LIJ. The last is the one used in this research. It is possible to check concordancing segments with COPA-CONC, to generate KWIC (Key Word in Context) lists, and to align texts with the AUTO ALIGNER tool.

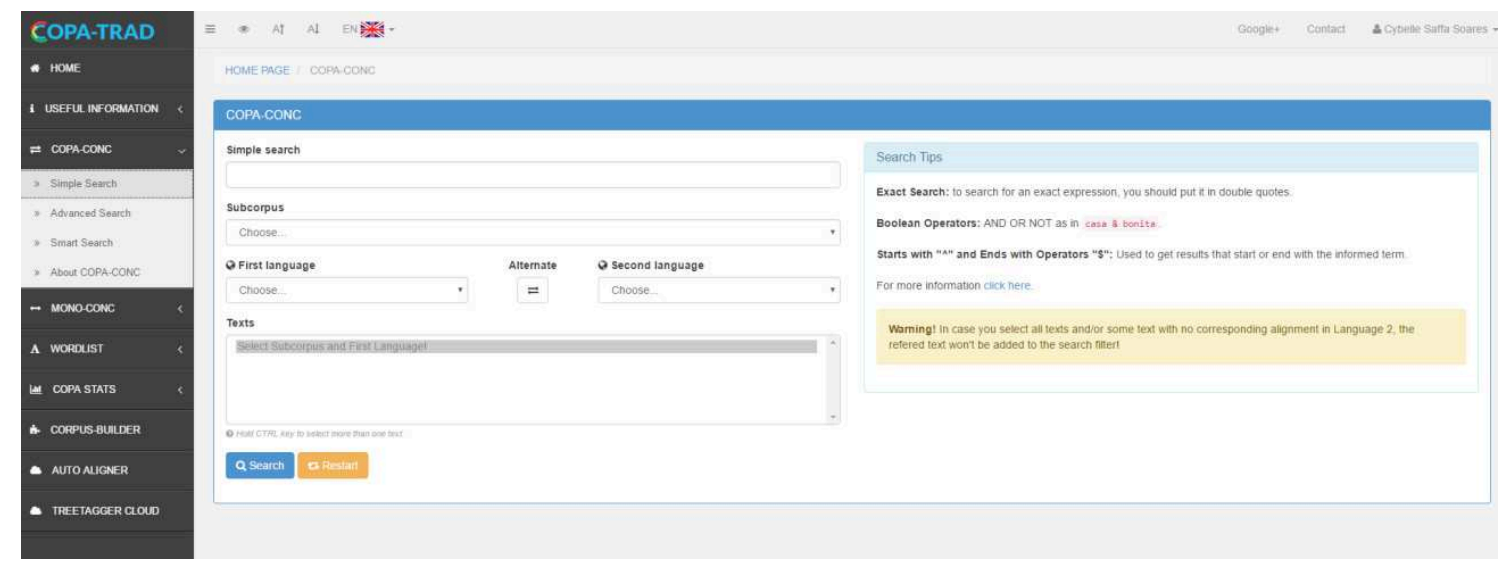

Figure 1. COPA-TRAD

With the COPA-CONC search tool, it was possible to identify the candidates for purification in the ST, namely, violence in the ST. In like manner, it was also possible to define and outline the probable purification categories in the ST. This tool allows the researcher to investigate ST and TT after a process of alignment that in COPA-TRAD can be done with the AUTO ALIGNER tool. COPA-CONC generates a search of a particular item from a specific sub-corpus. This parallel corpus tool provides searching, retrieval and cataloguing tools. According to Kenning (1998), parallel and comparable corpora are collections of electronic texts that are closely related to each other (p. 487).

\section{Superordinates: categories of violence in the sts}

Violence is textually represented by six nouns which compose the superordinate categories and by some verbs that are part of the hyponyms categories. The superordinate categories are: (i) killing and death threat; (ii) physical torture; (iii) mutilation; (iv) devouring; (v) beheading; (vi) cannibalism. The alignment process helped to identify the frequency of the categories of violence in the thirty-four STs. The figure below shows this frequency - clockwise: from the most to the least frequent. 


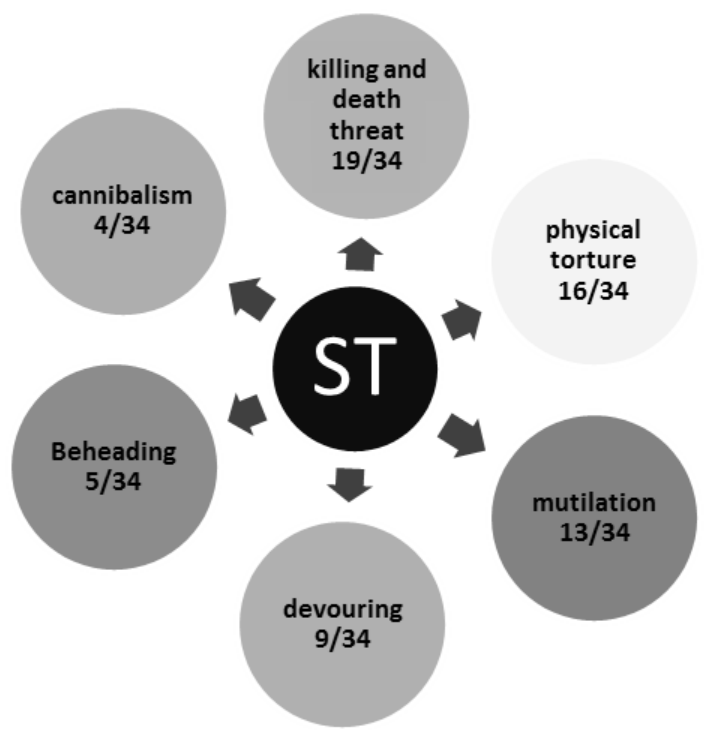

Figure 2. The frequency of categories of violence.

\section{Killing and death threat}

The hyponyms for this superordinate occurred in nineteen out of the thirtyfour fairy tales; they also show a high frequency of occurrences, which led this category to be the most recurrent in the STs. "Nix Nought Nothing" is the fairy tale with the greatest number of categories of violence: killing and death threat, physical torture, mutilation, devouring, and cannibalism. The most frequent hyponyms in this tale are: dash, drown and kill.

\section{Physical torture}

Physical torture is the second most frequent category among the STs analysed in this study. It occurred in sixteen of the thirty-four fairy tales and the most recurrent hyponyms listed as follows: souse (throw hot dishwater), baste (pour hot fat), scald (burn with hot liquid), boil, beat, dash, hit, strangle, bind, and choke. This category occurred in:

- How Jack went to seek his fortune;

- Nix Nought Nothing;

- Jack and the Beanstalk;

- The story of the three little pigs;

- The master and his pupil;

- Childe Rowland; Mollie Whuppie;

- The red ettin;

- Mr Fox;

- Kate Crackernuts;

- Fairy Ointment;

- The three head of the well; 
- $\quad$ Titty Mouse and Tatty Mouse.

\section{Mutilation}

The hyponyms identified in this category convey meanings of damage or severe disfiguration by cutting or violently removing body parts: cut off/into; hew (cut); crush (into pieces); snap up; chop off (one's head); moult (feathers).

Mutilation is the third most frequent category of violence in the STs. In some cases, identified as self-mutilation, but most occurrences presented the activities carried out by someone else. A total of thirteen fairy tales bring this category. "Nix Nought Nothing", "Jack and the Beanstalk", "Jack the Giant killer", "Childe Rowland, The History of Tom Thumb", "Mr Fox", and "Mr Miacca" are some of them.

\section{Devouring}

The purpose of attributing a distinct category for devouring and another for cannibalism was because not all characters that kill to eat in the fairy tales are cannibals. Most of them are giants slaying little boys for supper. There is a considerable amount of EFTs about giants, monsters and their intention to feast on scraps of little kids. "Jack and the Beanstalk" (with grind and have as hyponym), "Jack, the Giant Killer" (furnish, seise, feast, dine) "The red ettin" (kitchen meaning eat), and "Mr Miacca" (have). Os mais belos contos de fadas ingleses contemplated fairy tales of giants and ogres as a way of justifying the presence of bloodshed in its pages.

\section{Beheading}

Beheading, decapitating, cutting off or removing the head all imply that someone has been killed but not always done with the purpose of eating. Many are the English fairy tales about kings and queens assigning beheading as punishment. However, tales about giants recount the deeds of brave heroes who chop off the heads of giant creatures and deliver them to the kings as a symbol of might and bravery.

\section{Cannibalism}

This category of violence is recounted mainly in the omitted fairy tales. The remaining trace of cannibalism is discreetly veiled behind the spell that falls under Princess Margaret ("The Laidly Worm of Spindleston Heugh"), who turns into a terrible dragon by her stepmother who wishes to become queen and the most beautiful amongst all ladies of the realm. The other fairy tales that mention killing with the intention to eat are grouped under the devouring category. The characters involved in killing to eat: animals (a wolf, a fox, and a cat), giants and monsters; consequently, they do not fit the cannibalism category, for they do not eat animals of their kind. 


\section{Purification strategies explained}

\section{Deletion}

This purification strategy can be identified at the word (1), sentence (2) and paragraph (3) levels. When it happens, there is no substitution for an equivalent nor are rewordings of any kind made. A point often overlooked is the deletion at story level (4). This last type of deletion is chosen when the thematic of a fairy tale goes against the set of values of the target system. For this research, a deletion at story level left aside nine fairy tales that covered cannibalism, child abuse and child delinquency, reference to the devil, thievery, human bone maceration, and human murder. There was a total of nine excluded tales.

The translation of "Whittington and his cat" shows an apparent avoidance of descriptions of erring adults or improper behavioural representations of adults. The speeches of the cook cursing and calling Whittington names are deleted and in some instances are substituted for added and shorter explanations. There is a rewording of all the physical injuries perpetrated by the ill-natured cook and the cruellest actions, such as pouring hot fat or hot dishwater over the child, are deleted. All these alterations to the TT do not turn the cook into a nicer person; instead, her actions sound less violent and reinforce the fact that bad behaviour would have punishment as a consequence as can be seen in Table 3 below.

Table 3 - Whittington and his cat: deletion

\begin{tabular}{|c|c|}
\hline \multicolumn{2}{|c|}{ Deletion } \\
\hline ST & TT \\
\hline $\begin{array}{l}\text { Little Dick would have lived very hap- } \\
\text { pily in this good family if it had not } \\
\text { been for the ill-natured cook. She used } \\
\text { to say: "You are under me, so look } \\
\text { sharp; clean the spit and the dripping- } \\
\text { pan, make the fires, wind up the jack, } \\
\text { and do all the scullery work nimbly, } \\
\text { or--" and she would shake the ladle at } \\
\text { him. Besides, she was so fond of bast- } \\
\text { ing, that when she had no meat to baste, } \\
\text { she would baste poor Dick's head and } \\
\text { shoulders with a broom, or anything } \\
\text { else that happened to fall in her way. }\end{array}$ & $\begin{array}{l}\text { Mas não corria tudo à inteira satisfação } \\
\text { de Dick. Os criados fizeram dêle o alvo } \\
\text { dos seus chistes, ao passo que a mal } \\
\text { encarada e violenta cozinheira andava } \\
\text { às voltas com êle, encarregando-o de } \\
\text { inúmeros serviços, ameaçando romper- } \\
\text { lhe a crista com uma pancada se não } \\
\text { fizesse depressa o que ela mandasse. }\end{array}$ \\
\hline
\end{tabular}

In the TT the category of physical torture together with its hyponyms, such as basting or shaking the ladle, are rendered as pancada and her imposed orders are described instead of being uttered in the first person. The objects, such as a broom and a ladle, used to injure Whittington, are deleted and substituted by the word pancada. The characterisation of adults as vile and cruel is considerably justified for these deletions and substitutions. Instead, adult representation is through role models of good conduct and high Christian moral. 


\section{Added explanation}

This strategy seems to be recurrent in most TTs as to give a tone of adventure by stretching the description of events to justify the indiscriminate killing carried out by the heroes. "Jack o Matador de Gigantes" had eight whole paragraphs added to it. Moreover, this purification strategy can provide the target reader with a more detailed recount of the ST. For more detail about this strategy see (Soares, 2015, p. 82-82).

"João e o feijão" and "Jack o Matador de Gigantes" presented the largest amount of added paragraphs with added explanations that were not present in the respective STs. The additions can at times alter the meaning or the sequencing of events. In the case of the TT "João o Matador de Gigantes", the added explanations justified the brutal giant slaughter.

Table 4 - "Jack the Giant killer": added paragraphs to the TT

\begin{tabular}{c|l}
\hline ST & \multicolumn{1}{c}{ TT } \\
\hline & $\begin{array}{l}\text { Receberam-no com as melhores demonstrações de alegria. } \\
\text { Em sua honra, e para celebrar o êxito das suas façanhas, } \\
\text { deram uma grande festa, para a qual foram convidados } \\
\text { nobres e plebeus. Fizeram-lhe presente de lindo anel, em } \\
\text { que estava primorosamente gravado o gigante arrastando } \\
\text { um cavalheiro e uma dama [...] }\end{array}$ \\
\hline
\end{tabular}

These added explanations purified the massive bloodshed caused by both the giant and Jack himself. In this fashion, the added explanation can justify Jack's killing because he is always trying to free the people from the vicious assaults carried out by the Giants coupled with Jack's self-defence turning him into a hero in the end.

\section{Substitution for an equivalent}

In the translation of fairy tales, this strategy works more often at the word level, and the rendering can present itself at the level of small chunks. To demonstrate, we have the example of "Tom Tit Tot", the English version of Rumpelstiltskin in which the sentence personagenzinha singular substitutes the adjective maliceful. In “João o Matador de Gigantes", Lucifer becomes feiticeiro.

Table 5 - "Jack the Giant killer": substitution for an equivalent.

\begin{tabular}{l|l}
\hline \multicolumn{1}{c|}{ ST } & \multicolumn{1}{c}{ TT } \\
\hline $\begin{array}{l}\text { When she entered the place of the Old } \\
\text { One, she gave the handkerchief to old } \\
\text { Lucifer }\end{array}$ & $\begin{array}{l}\text { Quando a dama se juntou por fim ao } \\
\text { feiticeiro, entregou-lhe o lenço }\end{array}$ \\
\hline
\end{tabular}


This strategy to substitute Lucifer for feiticeiro reveals the influence of Christian principles that permeated the Brazilian society of the time of the translation of this tale.

The translations of the hyponyms for the word killing also bring examples of this strategy. Some words are substituted for others with a lighter connotation, such as in "Nix Nought Nothing: dash the head" translated to arremessar o rapaz; dash the brains is translated to matou.

The avoidance of mutilation is recurrent in "Jack and the Beanstalk". There are mentions of pieces of a dead boy turned into the pieces of an animal: scraps of that little boy you liked so much for yesterday's dinner $\leftrightarrow$ cheiro do sangue dos dois vitelos que trouxeste. The word veal substitutes the word boy, and no further description is added such as eating, meal, likes or dislikes. Sharing a meal substitutes the giant's intentions of feasting on Jack (e.g. who might share in the meal on Jack $\otimes$ para comer com ele).

\section{Rewording}

This purification strategy can often change the chronological sequence of a plot to make the series of events clearer and more coherent. Correspondingly, it can be used to add meaning to egregious violent scenes with the aim of softening and adding tones of justified violence. Strategy saw in conjunction with an added explanation. It provides further detail to a scene not to mention that it might add some features to characters as to make the villain scarier and more fearsome and the hero braver and bolder. "Jack, the giant killer", provides a significant number of instances of rewordings as to intensify the giant's might and rage.

Table 6 - Rewording

Jack, the giant killer

\begin{tabular}{l|l} 
"You must show me that handkerchief & - Estimado senhor, tereis de vos \\
to-morrow morning, or else you will & sujeitar aos costumes do meu palácio. \\
lose your head." & Amanhã de manhã me direis a quem \\
entreguei êste lenço; se não adivin- \\
hardes, perdereis a cabeça.
\end{tabular}

In other instances, the rewording simplifies and dries up detailed descriptions of cruelty to animal and children. In the following example from "The ass, the table, and the stick", the hyponym pull is moved to the end of the extract rewording the loud cry of pain of the donkey purifying the infliction of physical torture upon the defenceless animal. 
Table 7 - Rewording

The ass, the table, and the stick

[...] pull_Neddy's ears to make him begin at once to ee--aw! And when he brayed there dropped from his mouth silver sixpences, and half-crowns, and golden guineas. dando-lhe um jumento que, para por pela boca moedas de ouro e prata, bastava que lhe puxassem a orelha.

By and large, this strategy rearranges the meaning of a paragraph and brings the TT closer to the dominant set of moral values. Coelho (1987) goes on to say that the TCL in Brazil helped to maintain the cultural, religious, educational, and moral values as well as a way of avoiding undesirable behaviour and taboos. With this in mind, Arroyo (2010) understands that the literature for children in Brazil implied an educational purpose and should teach the young ones to behave.

\section{Motivational factors}

The TT reflected the prevailing moral and religious values inherited from the Catholic Church. Under those circumstances, representations of poorly behaved children led to punishment as to teach them how to behave and what would the consequences be if they did not follow the rules. Consequently, examples of misbehaviour and unacceptable conduct were represented by magic creatures such as giants, ogres and demons, and outlaws who deviated from societal highly moral accepted standards. Unwise boys who did not care about their parents' advice would respond to their misbehaviour. Tatar (2002) emphasises that "in bringing to life the dark figures of our imaginations as ogres and giants, fairy tales may stir up dread, but in the end always supply the pleasure of seeing it vanquished (p. xiv). It is the most corroborative evidence to justify the reasons why violence remains in the TT.

The heroes, likewise, would avenge the defenceless ladies, and unprotected children; with this intention, they would have all the difficulty obviated from their heroic rescue journey and in the end they would indeed succeed because of their daring deeds. In that case, the remaining gory details and indiscriminate killing in the TT are justified under the premise of having the hero defeating the enemies and saving the defenceless ladies from the evil charmed murderers.

\section{Final remarks}

This study set out to propose and to describe the purification strategies in the translation of violence of EFTs within the pair English $\leftrightarrow$ Portuguese. The final analysis of the TT Os mais belos contos de fadas ingleses mainly reflected the moral standards of Portuguese Christian society. The translation strategies mirrored sound principles of conduct and bravery. Translation does not happen whenever a fairy tale provided a high frequency of some questionable behaviour. 
Furthermore, the analysis yielded some probable motivational factors that might have guided the choices for each purification strategy.

Most compelling evidence uncovered from the analysis showed that the excluded fairy tales shared representations of the supernatural and the summoning of demons. Morbid and thanatological descriptions with mentions of graveyard, corpses, and the mutilation of recently deceased people, the use of the bones through a maceration in which the body goes through a process of defleshing and all internal organs removed. These are happenings described in Binnorie. So, when a fairy tale presented such themes that conveyed questionable adult behaviour, these would imply significant alterations that could lead to changing the meaning of the source text. There is no translation in cases like these. The Victorian Era has a high frequency of representations of death, and according to Jacobs (1981), the EFTs reflect that in their plots. The remaining descriptions of corpses and skeletons hereupon managed to continue in some of the TTs (e.g. "Jack the giant killer" and "Mr Fox") as a means of describing and emphasising the heroic deeds performed by the good guys.

The avoidance of representations of the uncanny, such as the deceased returning to claim their belongings or even stolen body parts, would go against the prevailing idea of innocence in childhood. The child should be taught to be good, and the fairy tales here analysed brought models of punished deviant behaviour and praise exemplary ones. The history of Tom Thumb reaches the limits of punishment, such as thievery with death. The little Tommy Grimes in "Mr Miacca" learns the lesson for not running from his mother and escapes death.

Another aspect revealed from the analysis is the purification as regards violence to animals. "The well of the world's end" is one example. Nasty frog is substituted by simples rã in the TT as shown in Table 8 .

Table 8 - Substitution for an equivalent

\begin{tabular}{l|l}
\hline \multicolumn{2}{c}{ The well of the world's end } \\
\hline "Girls must keep their promises," said & - As môças devem cumprir o que \\
the stepmother. "Go and open the door & prometem - disse a madrasta - . Abre \\
this instant." For she was glad the girl & $\begin{array}{l}\text { a porta já. Estava satisfeita que sua } \\
\text { enteada tivesse que obedecer a uma } \\
\text { would have to obey a nasty frog. }\end{array}$ \\
\hline
\end{tabular}

The low occurrence of thievery is justified by the intention of teaching the child the lesson that this kind of behaviour is certainly to be punished with imprisonment. Molly Whuppie's example of stealing is purified through the substitution of steal for privar/tirar which conveyed a metaphorical meaning of the given ST hyponym. The character justifies her private pilfering actions because she takes from a cruel and fierce giant whose hobby is to slaughter defenceless little boys and girls. So in the end, Molly Whuppie does not steal from the giant, she takes from him to raise her little sisters and prevent them from starvation.

In the final analysis, the motivational factor of the TT Os mais belos contos de fadas ingleses mirrored the Portuguese strict Christian morality and served 
as an ethical guide for the proper upbringing of children. The present research has hopefully contributed to unveil some of the first translation practices of children's literature in Brazil from the beginning of the twentieth century and the underlying motivational factors.

Notes

1. Houaiss, D. E. (2009). Versão 3.0. São Paulo: Objetiva.

2. My own translation for [violência - qualidade do que é violento].

\section{References}

Arroyo, L. (2010). Literatura Brasileira (3rd ed.). São Paulo: Editora Unesp.

Bertoletti, E.N. M. (2012). Lourenço Filho e a literatura infantil e juvenil. São Paulo: Editora Unesp.

Blamires, D. (2006). The early reception of the Grimm's Kind-und Hausmärchen in England. In G. Lathey (Ed.), The translation of children's literature - A reader (pp. 163-174). Clevedon: Multilingual Matters.

Bottigheimer, R. B. (2000). Germany. In J. Zipes (Ed.), The Oxford Companion to fairy tales (p. 208). Oxford: Oxford University Press.

Chatton, B. A. (1995). Children's books and their creators. (A. Silvey, Ed.). Boston, New York: Houghton Mifflin Company.

Chesterman, A. (1997). Memes of translation: the spread of ideas in translation theory (Vol. 22). Amsterdam and Philadelphia: John Benjamins Publishing. http://doi. org/10.1075/blt.123

Coelho, N. N. (1987). A tradução: núcleo geratriz da literatura infantil/juvenil. Ilha Do Desterro, 17, 21-32.

Fernandes, L. \& Silva, C. (2014). COPA-TRAD (Corpus Paralelo de Tradução). Retrieved from http://copa-trad.ufsc.br

Hatim, B. \& Munday, J. (2004). Translation: an advanced handbook. London and New York: Routledge.

Holbrook, A. L. (2009). Violence. In D. Matsumoto (Ed.), The Cambridge Dictionary of Psychology (p. 570). Cambridge: Cambridge University Press.

Jacobs, J. (1891). English fairy tales. London. (n.p).

Jacobs, J. (1980). English fairy tales. London. (n.p).

Kenning, M-M. (1998). What are parallel and comparable corpora and how can I use them? In O'Keeffe, A. \& McCarthy, M. (Ed.), The Routledge Handbook of Corpus Linguistics (pp. 487-500). London and New York: Routledge.

Klingberg, G. (1986). Children's Fiction in the Hands of the Translators. Lund, Sweden: Gleerup.

Malarte-Feldman. (2008). The Greenwood Encyclopedia of Folktales and Fairy Tales, Volumes 1-3. In D. Haase (Ed.) (Vol. 1 A-F, pp. 43-44). Westport: Greenwood Press.

Nodelman, P. (2008). The Hidden Adult. Baltimore: John Hopkins University Press.

Soares, C. S. (2015). The purification of violence and the translation of fairy tales: a corpus-based study. Dissertação (mestrado) - Universidade Federal de Santa Catarina, Centro de Comunicação e Expressão, Programa de Pós-Graduação 
em Inglês: Estudos Linguísticos e Literários, Florianópolis, 2015. Retrieved from https://repositorio.ufsc.br/xmlui/handle/123456789/160787.

Tatar, M. (1993). Off with their heads: fairy tales and the culture of childhood. Princeton: Princeton University Press.

(1999). Sex and violence: the hard core of fairy tales. In M. Tatar (Ed.), The Classic Fairy Tales (pp. 364-373). New York and London: W. W. Norton \& Company Ltd.

. (2002). Introduction. In M. Tatar (Ed.), The annotated classic fairy tales. New York and London: W. W. Norton \& Company Ltd.

Zilberman, R. (2003). A literatura infantil na escola (11th ed.). São Paulo: Global.

Zipes, J. (1999). The oral and literary fairy tales. In M. Tatar (Ed.), The Classic Fairy Tales (1st ed., pp. 333-338). New York and London: W.W. Norton.

Recebido em: 24/04/2017

Aceito em: 24/04/2018 